\title{
TAK ZWANA POSTULATURA PALLOTYŃSKA PROCESU BEATYFIKACYJNEGO S. FAUSTYNY KOWALSKIEJ
}

\section{Wstęp}

Kult Miłosierdzia Bożego, który za sprawą objawień św. s. Faustyny Kowalskiej (1905-1938) ${ }^{1}$, został rozpowszechniony w świecie dzięki jego promotorom, do których w pierwszym rzędzie zaliczyć należy bł. ks. Michała Sopoćko ${ }^{2}$ oraz zgromadzenia zakonne pallotynów i marianów, jak również sióstr Matki Bożej Miłosierdzia ${ }^{3}$. Przeszedł on skomplikowaną drogę usankcjonowania prawno-kościelnego, przełamując barierę dyrektyw Świętego Oficjum łącznie z Notyfikacją z 6 III 1959 r., która zakazywała szerzenie kultu Miłosierdzia Bożego w formie podanej przez s. Faustynę Kowalską w Dzienniczku ${ }^{4}$.

Notyfikacja Świętego Officjum była, jak twierdził ks. Julian Chróściechowski MIC, nieumiejętnością wskazania podstaw teologicznych orędzia s. Faustyny poczynioną przez wydawców różnych książeczek, artykułów i ulotek ${ }^{5}$. Tę samą myśl przedstawił w swoich wspomnieniach bł. ks. Michał Sopoćko, uważając za konieczne uzasadnienie kultu Miłosierdzia Bożego w aspekcie dogmatycznym, liturgicznym

\footnotetext{
${ }^{1}$ E. S i e p a k, Kowalska Faustyna, [w:] Encyklopedia katolicka, t. 9. Lublin 2002, kol. 1085.

${ }^{2}$ H. C i e r e s z k o, Ks. Michał Sopoćko promotor kultu Miłosierdzia Bożego. Saeculum Christianum, R. 11: 2004, nr 2, s. 101.

${ }^{3}$ T. B ł a s z c z y k, Wkład Pallotynów w rozwój kultu Miłosierdzia Bożego, [w:] Kościót w Polsce, Dzieje i kultura, red. J. W a 1 k u s z, t. 17, Lublin 2018, s. 270.

${ }^{4}$ Acta Apostolicae Sedis, 51(1959) Ser. III, vol. I, Nr 5, s. 271.

5 Archiwum Pallotynów w Częstochowie (dalej: ASACCz), Historia kultu Miłosierdzia Bożego. Interpretacja zarządzeń Św. Officjum. [J. C h r ó ś c i e c h o w s k i, Interwencja Najwyższej Kongregacji Świętego Officjum, s. 1], b. sygn.
}

„Nasza Przeszłość” t. 132: 2019, s. 363-395. 
i psychologicznym ${ }^{6}$. Ponadto krytycznie ocenił naukowe przedłożenia prelegentów związanych z KUL-owskim ośrodkiem naukowym wygłoszone podczas pierwszego sympozjum teologicznego poświęconego tematyce Miłosierdzia Bożego, zorganizowanego przez pallotynów 17 XI 1966 r. w Częstochowie. Sympozjum to miało być wkładem pallotynów do ogólnopolskich obchodów Sacrum Poloniae Millenium $^{7}$. Materiały sympozjalne ujrzały światło druku w pracy zbiorowej pod redakcją ks. prof. dr hab. Wincentego Granata pt. Ewangelia miłosierdzia ${ }^{8}$. Ks. Michał Sopoćko zarzucił autorom desyderatów, że: „Nie odróżniają miłosierdzia jako doskonałości Bożej od miłosierdzia jako cnoty"". Nie mniej jednak miał świadomość, podobnie jak ks. Stanisław Wierzbica SAC, że jest to kolejny krok w zgłębianiu tajemnicy Miłosierdzia Bożego poprzez poszukiwanie doktrynalnych podstaw w ramach naukowych przedłożeń ${ }^{10}$.

Ks. Michał Sopoćko, jak również pozostali propagatorzy kultu Miłosierdzia Bożego, w tym pallotyni na czele z ks. Stanisławem Suwałą SAC, krytycznie odnosili się do łączenia kultu Miłosierdzia Bożego z kultem Najświętszego Serca Pana Jezusa. Szczególnie poirytowani byli opinią o. Jana Rostworowskiego SJ, który uważał kult Miłosierdzia Bożego za zbyteczny, ponieważ zawiera się w kulcie Serca Jezusowego. Jego opinia była na tyle niepokojąca, że wiązała się z oświadczeniem zwalczania kultu Miłosierdzia Bożego „tak w kraju, jak i w Rzymie, dopóki Stolica Apostolska go nie zatwierdzi"11. Również ks. Stanisław Skudrzyk SJ z Melbourne w liście do ks. Stanisława Suwały SAC z dnia 1 V 1953 r., pisząc o Miłosierdziu Bożym, ujmował je jako «Miłosierdzie, które wypłynęło z Bożego Serca na Krzyżu»" i uważał, że jest to: „nowe ożywienie nabożeństwa do Najświętszego Serca Jezusowego" "12. Jak się okazuje nie były to odosobnione opinie, gdyż jak

\footnotetext{
${ }^{6}$ M. S o p o ć k o, Dziennik. Białystok 2015, s. 123.

${ }^{7}$ ASACCz, Korespondencje 1961-1969. [List do bpa Stefana Bareły z dn. 21 X 1966 r.], b. sygn.

${ }^{8}$ Poznań-Warszawa 1970, ss. 420.

${ }^{9}$ M. S o p o ć k o, Dziennik, s. 306.

${ }^{10}$ S. T y 1 u s, Leksykon polskich pallotynów (1915-2012), Ząbki-Poznań 2013, s. 602.

${ }^{11}$ M. S o p o ć k o, Dziennik, s. 125.

12 Archiwum Regi Miłosierdzia Bożego w Paryżu (dalej: ARMBP), Miłosierdzie Boże. Siostra Faustyna, [list o. Skudrzyka SJ do ks. Stanisława Suwały SAC z dn. 1 V 1953], b. sygn.
} 
przypomina ks. Stanisławowi Suwale SAC w swoim liście ks. Henryk Malak, tercjarz franciszkański z Wisconsin, bł. s. Maria Angela Truszkowska, założycielka felicjanek ${ }^{13}$, wprowadziła w swoich klasztorach kult Miłosierdzia Bożego, traktując je jako nabożeństwo do Krwi Przenajświętszej „Z wyraźnym podkreśleniem jako źródła miłosierdzia"14. Innego zdania był ks. prof. Ignacy Różycki, wybitny dogmatyk, związany z takimi uczelniami, jak krakowski UJ i PAT oraz warszawską ATK ${ }^{15}$. W swoim sympozjalnym referacie wygłoszonym $\mathrm{z}$ okazji 50 . rocznicy objawienia s. Faustynie Kowalskiej obrazu Miłosierdzia Bożego wskazał na subtelną, a jakże znaczącą różnicę między obydwoma nabożeństwami. W swoim przedłożeniu zaznaczył, że: „Przedmiot nabożeństwa do Miłosierdzia jest swym zakresem różny i szerszy od właściwego przedmiotu nabożeństwa do Jezusowego Serca", mimo że wydawać by się mogło, że nie ma tutaj istotnej różnicy, a: „Nabożeństwo do Serca Jezusowego mieści się w nabożeństwie do Miłosierdzia, jako część całości" ${ }^{16}$.

Sprzeciw ks. Michała Sopoćki i pallotynów w sprawie łączenia kultu Miłosierdzia Bożego z kultem Najświętszego Serca Pana Jezusa nie oznaczał wcale braku wyrobienia teologicznego, bo byli przecież wytrawnymi teologami, by nie rozumieć istoty obydwu kultów, czego wyraz dał ks. Roman Forycki SAC w swoim referacie podczas drugiego sympozjum teologicznego w 1968 r. ${ }^{17}$. Ich sprzeciw związany był raczej $\mathrm{z}$ ewentualną możliwością zaniechania działań związanych z uznaniem kultu Miłosierdzia Bożego przez odpowiednie władze kościelne, jak również z beatyfikacją s. Faustyny Kowalskiej.

13 J. M a c hnia k, Maria Angela Truszkowska, [w:] Encyklopedia katolicka, t. 11, Lublin 2006, kol. 1298.

${ }_{14}$ ARMBP, Miłosierdzie Boże..., [list ks. Henryka Malaka do ks. Stanisława Suwały SAC z dn. 16 V 1955 r.], b. sygn.

${ }^{15}$ G. R y ś, Różycki Ignacy, [w:] Słownik Polskich Teologów Katolickich, red. J. M a n d z i u k, t. 8, Warszawa 1995, s. 495.

16 I. R ó ż y c k i, Zasadnicze rysy nabożeństwa do Miłosierdzia Bożego, Wiadomości Diecezjalne, Organ Urzędowy Kurii Diecezjalnej w Katowicach, R. 57: 1989, nr 3, s. 113.

${ }^{17}$ R. F ory c ki, Kult Miłosierdzia Bożego w świetle encykliki „Haurietis Aquas”, [w:] Powołanie człowieka, t. 2, „...Bo Jego Miłosierdzie na wieki” (Ps. 135). PoznańWarszawa 1972, s. 97-103. 


\section{Zaangażowanie Pallotynów w krzewienie kultu Miłosierdzia Bożego}

Fascynacja heroicznością cnót s. Faustyny Kowalskiej i intuicyjna pewność nadprzyrodzonego pochodzenia jej objawień sprawiała wielkie zainteresowanie osobą przyszłej świętej i podjęcia działań zmierzających do rozszerzania kultu Miłosierdzia Bożego i wszczęcia procesu beatyfikacyjnego. Niewątpliwą zasługą w tym zakresie wykazali się polscy pallotyni we Francji, których większość przeszła obozy koncentracyjne, gdzie współwięźniowie zapoznali ich z orędziem Miłosierdzia Bożego. Tak było w przypadku długoletniego rektora Polskiej Misji Katolickiej we Francji, ks. Franciszka Cegiełki SAC (1908-2003), który był więźniem obozów nazistowskich w Sachsenhausen i Dachau ${ }^{18}$. To właśnie w Dachau ks. Stefan Ogrodowski, proboszcz Krotoszyna, zapoznał go z koronką do Miłosierdzia Bożego, prosząc o jej rozkrzewianie $^{19}$. Ks. Franciszek Cegiełka SAC był przekonany, że dzięki tej modlitwie s. Faustyna Kowalska wyprosiła mu w trudnych chwilach obozowego życia powrót do zdrowia i cudowne ocalenie ${ }^{20}$.

To między innymi za jego przyczyną w momencie przekształcania pallotyńskiej Delegatury francuskiej w Regię (2 VIII 1946) byli pallotyńscy więźniowie hitlerowskich obozów optowali za nadaniem jej tytułu „Miłosierdzia Bożego”, jako dowód wdzięczności Bogu za opatrznościowe przetrwanie wojny i obozów koncentracyjnych ${ }^{21}$. Nawet interweniowali u samego generała pallotynów kiedy Rada Generalna zmieniła proponowaną nazwę na Chrystusa Miłosierdzia. Nacisk polskich pallotynów, pracujących w Regii i interwencja ks. Karla Hoffmanna SAC, generała zakonu, skłoniła Radę Generalną

\footnotetext{
18 J. B a k a 1 a r z, Francja. Kościót katolicki, F. Duszpasterstwo polonijne, [w:] Encyklopedia katolicka, t. 5. Lublin 1989, kol. 616; F. G o m u ł c z a k, Cegietka. Pasterz Polonii. Ząbki 2014, s. 111.

${ }^{19}$ F. G o m ułc z a k, Cegietka..., s. 120.

20 A. M. P i etrzy k, Pallotyni zawsze wierzyli $w$ prawdziwość przesłania siostry Faustyny, Annuntianda, R. 24: 2016, nr 265, s. 64.

${ }^{21}$ L. B a lt e r, Wstęp, [w:] Powołanie człowieka, t. 2: „...Bo Jego Miłosierdzie na wieki”, s. 6; S. T y lu s, Prace polskich pallotynów wśród emigracji (do utworzenia francuskiej regii Miłosierdzia Bożego - 2 VIII 1946), Archiwa, Biblioteki i Muzea Kościelne, t. 66: 1996, s. 515.
} 
20 XII 1946 r. do przywrócenia pierwotnie proponowanego brzmienia tytułu Regii ${ }^{22}$.

Polscy pallotyni nie szczędzili wysiłków na rzecz krzewienia kultu Miłosierdzia Bożego tak w formie organizowanych nabożeństw oraz sympozjów, jak i opracowań naukowych i popularno-naukowych ${ }^{23}$. Na uwagę zasługuje tutaj bibliografia ks. Franciszka Cegiełki SAC i Alojzego Misiaka SAC, którzy opisywali historię kultu Miłosierdzia Bożego, jak również rysy duchowości s. Faustyny Kowalskiej z uwzględnieniem jej biografii ${ }^{24}$. Nie mniejszą wagę posiadają opracowania ks. Juliana Chróściechowskiego $\mathrm{MIC}^{25}$ oraz ks. Józefa Jarzębowskiego MIC, który pierwsze materiały o kulcie Miłosierdzia Bożego wg objawień s. Faustyny przywiózł do Ameryki ${ }^{26}$. Część materiałów, które otrzymał od ks. Michała Sopoćki, przewiózł w 1941 r. z Wilna transportem transsyberyjskim do Władywostoku, skąd przez Japonię dotarł do Stanów Zjednoczonych, gdzie w Waszyngtonie dokonał przedruku broszury pt.: Ojciec Miłosierdzia ${ }^{27}$. Zaangażowanie ks. Józefa Jarzębowskiego MIC w szerzenie kultu Miłosierdzia Bożego wg form podanych w Dzienniczku przez s. Faustynę wiązało się z uroczystym ślubem dozgonnego poświęcenia się szerzeniu kultu Miłosierdzia Bożego, jeśli szczęśliwie ujdzie z życiem przed ścigającym go hitlerowskim okupantem ${ }^{28}$.

Cenną pozycją wydaje się być opracowanie pt. „Siostra FaustynaApostołka Miłosierdzia Bożego" autorstwa Dr H.[elimenasa] W.[ojczu-

${ }^{22}$ S. T y l u s, Kalendarium dziejów Regi Miłosierdzia Bożego (1946-2016). Warszawa 2017, mps, s. 9-10.

${ }^{23}$ T. B ł a s z c z y k, Wkład Pallotynów w rozwój kultu Miłosierdzia Bożego, s. 273-293.

${ }^{24}$ F. C e g i e ł k a, Siostra Faustyna Kowalska - Szafarka Miłosierdzia Bożego, Nord Tonawanda 1954, ss. 396; T e n ż e, Z historii kultu Miłosierdzia Bożego w świecie, Collectanea Theologica, R. 1982, nr 1, s. 145-156; A. M is i ak, O Miłosierdziu Bożym. Wyjątki z „Dzienniczka” siostry Faustyny (ze Zgromadzenia Matki Boskiej Miłosierdzia), Paryż 1953, ss. 160; T e nż e, Siostra Maria Faustyna a Matka Najświętsza, Nasza Rodzina, R. 1955, nr 5, s. 78-79.

25 J. C h róś c i e c how s k i, Historia nabożénstwa do Miłosierdzia Bożego w naszych czasach, Lower Bullingham, Hereford 1977, wyd. 3 poszerzone, ss. 151.

${ }^{26}$ A. B e d n a r e k, Jarzębowski Józef MIC, [w:] Encyklopedia katolicka, t. 7, Lublin 1997, kol. 1057.

27 ARMBP, Miłosierdzie Boże... [list ks. Juliana Chróściechowskiego MIC do ks. Stanisława Suwały SAC z dn. 26 I 1976 r.], b. sygn.

${ }^{28}$ Ku czci Bożego Miłosierdzia. [w:] Dzienniczek Stugi Bożej S. M. Faustyny Kowalskiej Profeski wieczystej Zgromadzenia Matki Bożej Miłosierdzia. Kraków 1983, s. 728. 
nasa], pod którym to kryptonimem skrywał się o. Kazimierz Sykstus Szafraniec ZP ${ }^{29}$. Książka ta wydana w Osny w 1953 r. przez pallotynów w języku francuskim została przekazana marianom, którzy wydali ją w języku angielskim ${ }^{30}$.

Pallotyni zabiegali także o rzetelną biografię s. Faustyny, proponując Marii Winowskiej jej opracowanie, zwłaszcza że znali jej wcześniejsze studium związane z życiem o. Maksymiliana Marii Kolbego. Wówczas polska pisarka emigracyjna negatywnie ustosunkowała się do propozycji pallotynów, oświadczając wręcz, że sprawa s. Faustyny i Miłosierdzia Bożego nie leży w kręgu jej zainteresowania, jest jej obca, a brak odpowiedniego czasu nie pozwala jej na rzetelną pracę badawczą $^{31}$. Dopiero w 1956 r. zwróciła się do ks. Stanisława Suwały SAC z prośbą o możliwość napisania odpowiedniej książki dotyczącej problematyki wcześniej proponowanej przez pallotynów ${ }^{32}$. Tym sposobem powstało jej autorstwa obszerne dzieło dotyczące Miłosierdzia Bożego i życia s. Faustyny ${ }^{33}$.

\section{Pierwsze kroki działań na rzecz beatyfikacji s. Faustyny}

Śmierć s. Faustyny Kowalskiej (†5 X 1938) nie osłabiła zainteresowania ani jej osobą ani kultem Miłosierdzia Bożego, które rozszerzało się dynamicznie. Olbrzymi wkład w tym dziele ma ks. Michał Sopoćko, który od s. Faustyny usłyszał nakaz głoszenia światu o Miłosierdziu Bożym ${ }^{34}$. Jeszcze w 1938 r. przygotował dla biskupów polskich memoriał dotyczący święta Miłosierdzia Bożego. Podczas swojego pobytu w Częstochowie dn. 23 IX 1938 r. na Zjeździe Katolickiego Stowarzyszenia Młodzieży z niektórymi z nich rozmawiał osobiście, otrzymując zapewnienie, że nie będą wyrażać sprzeciwu

\footnotetext{
${ }^{29}$ ARMBP, Miłosierdzie Boże..., [list ks. Juliana Chróściechowskiego MIC do ks. Stanisława Suwały SAC z dn. 6 VI 1976 r.], b. sygn.

30 Tamże.

31 Tamże, [list ks. Stanisława Suwały SAC do s. Ksawery Olszamowskiej z dn. 3 III 1957 r.], b. sygn.

32 ARMBP, Miłosierdzie Boże..., [list ks. Stanisława Suwały SAC do s. Ksawery Olszamowskiej z dn. 3 III 1957 r.], b. sygn.

${ }^{33}$ M. W i now s k a, Droit á la Miséricorde, Paryż 1958, ss. 279; T a ż, L'lcône du Christ Miséricordieux. Message de Soeur Faustine, Paryż 1973, ss. 297; T a ż, Prawo do Miłosierdzia. Posłannictwo siostry Faustyny. Paryż 1974, ss. 277.

${ }^{34}$ M. S o p o ć k o, Dziennik, s. 98.
} 
dla święta Miłosierdzia Bożego w Niedzielę Przewodnią ${ }^{35}$. Natomiast podczas uroczystości wielkanocnych 1939 r., które przeżywał w Rzymie, miał zamiar przedstawić w Watykanie sprawę święta Miłosierdzia Bożego. Cel nie został przez niego osiągnięty $\mathrm{z}$ powodu niemożności spotkania z hierarchami Sekretariatu Stanu i Kongregacji ds. Obrzędów. Spotkał się jedynie z Konsultorem Świętej Kongregacji Pro Ecclesia Orientali, ks. prałatem Stanisławem Janasikiem, który poinformował go o potrzebie protekcji Episkopatu Polski, bez której to nie będzie w stanie niczego uzyskać w sprawie Miłosierdzia Bożego ${ }^{36}$. Była to istotna informacja dla ks. Michała Sopoćki, która wskazywała prawną drogę w podejmowaniu jakiejkolwiek procedury kościelnej. Ponadto, mając świadomość obowiązującego od 26 V 1936 r. dekretu Kongregacji Świętego Officjum o niewprowadzaniu do liturgii kościoła nowych form kultu czy pobożności, posiadł w tym momencie głębokie zrozumienie dla dyrektyw biskupów polskich ${ }^{37}$. Uświadomił sobie tym samym, że wszelkie zabiegi o ustanowienie nowego święta, jak i uruchomienia procedury beatyfikacyjnej s. Faustyny zostaną uwzględnione przez Stolicę Apostolską jedynie na wniosek biskupów polskich ${ }^{38}$.

Śmierć s. Faustyny nie była dla niego żadnym zaskoczeniem, ponieważ był mocno przekonany o jej świętości, uważając, że ,jest to dusza ściśle zjednoczona z Bogiem, który sam nią kieruje i udoskonala przez

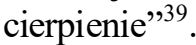

Kwestia heroicznej świętości życia Apostołki Miłosierdzia Bożego ponownie zainteresowała opinię publiczną w 1940 r. za sprawą cudownego uzdrowienia mieszkanki Warszawy, Barbary Klossównej za wstawiennictwem s. Faustyny ${ }^{40}$. Fakt ten sprawił, że przełożona

\footnotetext{
${ }^{35}$ M. S o p o ć k o, Dziennik, s. 109.

36 Tamże, s. 111.

${ }^{37}$ Tamże, s. 111; E. K i s i e 1, Bóg - Ojcem miłosierdzia, Biuletyn Miłosierdzia Bożego, R. 1984, nr 14, s. 57.

38 S. N ow a k, Ustanowienie święta Miłosierdzia $i$ jego konsekwencje pastoralne. [Referat wygłoszony podczas IV Międzynarodowego Kongresu Apostołów Bożego Miłosierdzia w Krakowie-Łagiewnikach, 3-5 października 2014], mps, s. 4.

${ }^{39}$ M. S o p o ć k o, Dziennik, s. 106, 109.

40 Archiwum Zgromadzenia Sióstr Matki Bożej Miłosierdzia w Krakowie (dalej: AZMBMKr.), Materiaty dotyczace przygotowania procesu informacyjnego s. Faustyny. [Ks. Alojzy Ż u c how s k i, Krakowska Diecezja. Sprawa Beatyfikacji i Kanonizacji Stużebnicy Bożej Marii Faustyny Kowalskiej Profeski Koadiutorki Zgromadzenia SS. Matki Bożej Miłosierdzia, s. 25], sygn. PC/I/1.
} 
generalna m. Michaela Moraczewska $(† 1946)$ zwróciła się do Prymasa Polski kard. Augusta Hlonda o podjęcie procedury związanej z przyszłą beatyfikacją s. Faustyny. Kardynał August Hlond pismem z dn. 9 I 1947 r. odpowiedział już nowej przełożonej generalnej m. Róży Kłobukowskiej, żeby Zgromadzenie zbierało dokumenty i gromadziło materiały dotyczące życia s. Faustyny, które będą potrzebne w momencie rozpoczęcia oficjalnej procedury beatyfikacyjnej, ponieważ obecna chwila jest jeszcze nieodpowiednia na jej podjęcie ${ }^{41}$. Jeszcze tego samego roku pismem z dn. 15 VII s. Róża Kłobukowska informowała ks. Prymasa, że uruchomiła już proces zbierania danych dotyczących życia s. Faustyny. Równocześnie wyposażyła s. Ksawerę Olszamowską we wszelkie pełnomocnictwa upoważniające ją do podejmowania, w imieniu Zgromadzenia, odpowiednich działań w sprawie beatyfikacyjnej s. Faustyny ${ }^{42}$.

W 1948 r. przełożona generalna Zgromadzenia Sióstr Matki Bożej Miłosierdzia wraz z ks. Michałem Sopoćko udali się do metropolity krakowskiego, ks. Adama kard. Sapiehy, składając pisemną prośbę o mianowanie postulatora, który przygotowałby proces informacyjny s. Faustyny. Ordynariusz krakowski, odnosząc się życzliwie do prośby, wykazał równocześnie pewną ostrożność, przekazując sufraganowi krakowskiemu ks. bp. Stanisławowi Rospondowi sprawę do rozpatrzenia i załatwienia ${ }^{43}$. Podczas kolejnego spotkania s. Ksawery Olszamowskiej z bp. Stanisławem Rospondem, u którego na biurku zauważyła wcześniej złożoną prośbę i upewnieniu się, że petycja ta nie znalazła się w toku rozpatrywania, postanowiła odebrać wniosek i uwolnić sufragana krakowskiego $\mathrm{z}$ dalszego procedowania sprawy ${ }^{44}$. Wówczas $\mathrm{w}$ imieniu Zgromadzenia, s. Ksawera Olszamowska, pozostając w bardzo dobrych relacjach z księżmi pallotynami ${ }^{45}$, zwróciła się do generała pallotynów ks. Wojciecha Turowskiego SAC, pismem z dn. 27 II 1951 r., z prośbą

41 P. S o c ha, Rozwój kultu Bożego Miłosierdzia w Polsce $i$ na świecie, Peregrinus Cracoviensis, R. 2000, z. 9, s. 126.

42 AZMBMKr., Materiaty dotyczace przygotowania procesu..., [s. Hieronima G r o b i c k a, Chronologiczne dane dotyczace przygotowań, przez M. Ksawerę Olszamowska, procesu informacyjnego s. Faustyny Kowalskiej w latach 1949-1959, s. 1], sygn. PC/I/1.

${ }^{43}$ M. S o p o ć k o, Dziennik, s. 122.

${ }^{44}$ M. S o p o ć k o, Dziennik, s. 122.

45 AZMBMKr., Materiały dotyczace przygotowania procesu..., [s. Hieronima G r o b i c k a, Chronologiczne dane..., s. 1], sygn. PC/I/1. 
o podjęcie trudu uruchomienia procedury beatyfikacyjnej s. Faustyny Kowalskiej i wyznaczenia postulatora, który całą sprawę usprawniłby w formule wymaganych przepisów kanonicznych, co do których norm Zgromadzenie Matki Bożej Miłosierdzia nie posiadało stosownej wiedzy ${ }^{46}$. W swoim liście informowała także ks. Wojciecha Turowskiego SAC, że opinia świętości s. Faustyny wzbudza wielkie zainteresowanie osób, które w czasie minionej wojny, ,zwracając się przez jej pośrednictwo do Miłosierdzia Bożego (...) otrzymały nieprzerwany ciąg łask"47. Ufając, że otrzyma pozytywną odpowiedź, prosiła także o wyznaczenie na wicepostulatora jakiegoś kapłana w Krakowie ${ }^{48}$.

Generał pallotynów odpowiadając pisemnie s. Ksawerze Olszamowskiej w dn. 22 V 1951 r., wyraził zgodę na pallotyńską postulaturę, informując ją, że pallotyni uczynią wszystko, co w ich siłach, „by pomóc $\mathrm{w}$ doniosłej dla Zgromadzenia i całego narodu polskiego sprawie, beatyfikacji siostry Marii Faustyny"49. W liście tym zaznaczył równocześnie, że na głównego postulatora został wyznaczony ks. Stanisław Suwała SAC, z którym odtąd należy uzgadniać wszystkie kwestie odnośnie beatyfikacji ${ }^{50}$. Natomiast przełożony polskiej prowincji stowarzyszenia, ks. Stanisław Czapla SAC, który w podległej mu prowincji był inicjatorem i propagatorem nabożeństwa i kultu Miłosierdzia Bożego w formie podanej przez s. Faustynę ${ }^{51}$, informował s. Ksawerę Olszamowską, że urząd wicepostulatora powierzył ks. dr. Janowi Maćkowskiemu SAC ${ }^{52}$.

\section{Czynności postulatorskie pallotynów}

Ks. Stanisław Suwała SAC, przyjmując obowiązki głównego postulatora, wyrażał pewne obawy w podołaniu zleconego zadania, jednakże:

\footnotetext{
${ }^{46}$ ARMBP, Miłosierdzie Boże..., [list s. Ksawery Olszamowskiej do generała pallotynów ks. Wojciecha Turowskiego SAC z dn. 27 II 1951 r.], b. sygn.

47 Tamże, [list generała pallotynów ks. Wojciecha Turowskiego SAC do s. Ksawery Olszamowskiej z dn. 22 V 1951 r.], b. sygn.

${ }^{48}$ Tamże.

49 Tamże, [list generała pallotynów ks. Wojciecha Turowskiego SAC do s. Ksawery Olszamowskiej z dn. 22 V 1951 r.], b. sygn.

50 Tamże.

${ }^{51}$ S. T y 1 u s, Leksykon polskich pallotynów 1915-2012, Ząbki-Poznań 2013, s. 128.

52 AZMBMKr., Materiały dotyczace przygotowania procesu..., [s. Hieronima G r o b i c k a, Chronologiczne dane..., s. 2], sygn. PC/I/1.
} 
„Z pewną trwogą (...) wziął na swoje barki ciężar odpowiedzialności” i zapewniał przełożoną generalną Zgromadzenia Matki Bożej Miłosierdzia w liście z dn. 25 VII 1951 r., że: „wykona swój urząd sumiennie i z poświęceniem" "53. Siostra Ksawera Olszamowska natomiast, zapewniając go o wszelkim wsparciu ${ }^{54}$, usilnie prosiła o powołanie wicepostulatora, który byłby gwarantem jednolitego prowadzenia sprawy nie tylko w Polsce, ale także poza jej granicami ${ }^{55}$. Ks. Stanisław Suwała SAC czynił zatem zabiegi, by wyznaczyć dodatkowego wicepostulatora na Europę zachodnią, którym został, z nominacji przełożonego Regii ks. Czesława Wędziocha SAC, ustanowiony ks. Alojzy Misiak SAC z Regii Miłosierdzia Bożego ${ }^{56}$. Równocześnie superior Regii przydzielił mu do pomocy ks. Leona Bemke SAC ${ }^{57}$.

Superior Regii Miłosierdzia Bożego, ks. Czesław Wędzioch SAC, w specjalnym okólniku informował wszystkich członków Regii, że nominacja ks. Alojzego Misiaka SAC jako wicepostulatora na Francję i Europę zachodnią związana jest $\mathrm{z}$ koordynowaniem wszystkich spraw dotyczących propagandy nabożeństwa do Miłosierdzia Bożego i z szerzeniem znajomości Apostołki tegoż nabożeństwa wśród wiernych we Francji ${ }^{58}$. Dla usprawnienia całej procedury związanej z postulaturą pallotyńską ustanowił przy nowicjacie w Osny sekretariat propagandy nabożeństwa do Miłosierdzia Bożego, a ks. Alojzemu Misiakowi SAC zlecił dodatkowo prowadzenie wyodrębnionego działu w „Naszej Rodzinie”, w którym zamieszczane miały być informacje dotyczące Miłosierdzia Bożego i uzyskanych łaskach za wstawiennictwem s. Faustyny ${ }^{59}$.

53 ARMBP, Miłosierdzie Boże..., [list ks. Stanisława Suwały SAC do Generalnej Sióstr Zgromadzenia Matki Bożej Miłosierdzia z dn. 25 VII 1951 r.], b. sygn.

54 Tamże, [list s. Ksawery Olszamowskiej do ks. Stanisława Suwały SAC z dn. 23 VI 1951 r.], b. sygn.

55 Tamże, [list s. Ksawery Olszamowskiej do ks. Stanisława Suwały SAC z dn. 14 X 1951 r.], b. sygn.; tamże, [list s. Ksawery Olszamowskiej do ks. Stanisława Suwały SAC z dn. 1 XI 1951 r.], b. sygn.

56 Tamże, [list ks. Czesława Wędziocha SAC do ks. Stanisława Suwały SAC z dn. 8 I 1952 r.], b. sygn.

57 Tamże.

58 ARMBP, Miłosierdzie Boże..., [Okólnik Przełożonego Regii do członków Stowarzyszenia Apostolstwa Katolickiego z dn. 5 I 1952 r.], b. sygn.

59 Tamże. 
Mimo, że ks. Alojzy Misiak SAC był sceptycznie ustosunkowany do wszelkich objawień prywatnych, o czym pisał 16 IX 1955 r. w swoim sprawozdaniu $^{60}$, i z tej racji bronił się przed podjęciem funkcji wicepostulatora, to wykonał rzetelną i wartościową pracę na rzecz rozwoju kultu Miłosierdzia Bożego i s. Faustyny Kowalskiej. W tym celu dodatkowo założył w 1954 r. periodyk Messager de la Miséricorde Divine, w którym m.in. wydrukował wyjątki z Dzienniczka s. Faustyny, a cały Dzienniczek przetłumaczony na język francuski wydał przy współudziale $\mathrm{z}$ wydawnictwem Hovin w 1984 r. ${ }^{61}$. Jego sceptycyzm dotyczący objawień s. Faustyny i związanego z nim procesu beatyfikacyjnego dotyczył trudności natury teologicznej. Uważał, że trudności te przymuszały pallotynów do naukowego pogłębienia istoty nabożeństwa oraz kontrolowania autentyczności wydawnictw ${ }^{62}$. Dlatego godząc się na wicepostulaturę dostrzegał potrzebę skoordynowanej akcji w sprawie tak kultu do Miłosierdzia Bożego, jak i beatyfikacji s. Faustyny, z wielu ośrodków pallotyńskich, m.in. z Belgii, Szwajcarii, Niemiec i Anglii, które bacznie obserwowały działania w tej materii głównego ośrodka pallotyńskiego we Francji ${ }^{63}$. Również ks. Stanisław Suwała SAC dostrzegał pilną potrzebę koordynacji działań tzw. pallotyńskiego ośrodka postulatorskiego. Uważał, że głównym priorytetem wszelkich działań jest w pierwszym rzędzie potrzeba szerzenia znajomości s. Faustyny Kowalskiej jako Apostołki Miłosierdzia Bożego, następnie wyniesienie ją na ołtarze, a dopiero w dalszej kolejności podjęcie starań o zatwierdzenie kultu Miłosierdzia Bożego ${ }^{64}$.

Napływające zewsząd informacje dotyczące kultu Miłosierdzia Bożego i s. Faustyny były wykorzystane do opracowania noty biograficznej przyszłej świętej i przedstawienia otrzymywanych łask za jej wstawiennictwem podczas prowadzonych przez pallotynów konferencji ascetycznych. Między innymi w archiwum Regi zachował się konspekt konferencji do kobiet z Akcji Katolickiej przeprowadzonej przez

60 Tamże, [ks. Alojzy Misiak SAC, Sprawa Akcji „Bożego Miłosierdzia” a Regia Francuska, mps, s. 1], b. sygn.

${ }^{61}$ A. M. P i e tr z y k, Pallotyni zawsze wierzyli..., s. 67.

62 ARMBP, Miłosierdzie Boże..., [ks. Alojzy Misiak SAC, Sprawa Akcji „Bożego Miłosierdzia"..., s. 1], b. sygn.

${ }^{63}$ Tamże.

${ }^{64}$ ARMBP, Miłosierdzie Boże..., [list ks. Stanisława Suwały SAC do ks. Alojzego Misiaka SAC z dn. 5 IV 1952 r.], b. sygn. 
ks. Stanisława Suwałę SAC w Rzymie 2 VI 1956 r. ${ }^{65}$. Przedstawiał w niej informacje o otrzymanych łaskach z takich miejscowości jak: Aleksandrii, Huise-Lozer w Belgii, Verdun, Brukseli, Martyniki, Vibo Valentia, Civitanova Marche czy Guyany holenderskiej ${ }^{66}$. Wykaz wymienionych łask odnosił się $\mathrm{m}$. in. do powrotu męża do ogniska domowego po 14 miesiącach rozłąki, uzdrowienia córki z choroby i jej nawrócenia, otrzymania posady czy też zdania przez córkę matury ${ }^{67}$.

Również abp Józef Gawlina pomagał pallotynom zaangażowanym w proces beatyfikacji s. Faustyny. Mając na uwadze ważność informacji o łaskach otrzymanych za wstawiennictwem Apostołki Miłosierdzia Bożego doręczył ks. Stanisławowi Suwale SAC list jaki otrzymał od ks. Jana Suchosa z Newport w USA, w którym opisany został cud zdziałany za pośrednictwem s. Faustyny. Bezpośrednia już korespondencja między ks. Stanisławem Suwałą SAC a ks. Janem Suchosem wykazała, że mąż jego siostrzenicy Stanisław Piecyk, któremu zdiagnozowano zapalenie otrzewnej i pęknięcie jelit, doznał cudownego uzdrowienia za wstawiennictwem s. Faustyny ${ }^{68}$. Ks. Jan Suchos w prowadzonej korespondencji informował ks. Stanisława Suwałę SAC, że cała rodzina łącznie z nim modliła się nowenną do Miłosierdzia Bożego, prosząc Miłosiernego Jezusa o skuteczne wstawiennictwo s. Faustyny w sprawie uzdrowienia Stanisława Piecyka ${ }^{69}$. Ks. Stanisław Suwała SAC, dziękując ks. Janowi Suchosowi za podane informacje zadeklarował, że opisany przez niego cud zostanie opublikowany w miesięczniku wydawanym przez Regię Miłosierdzia Bożego celem pobudzenia czcicieli Miłosierdzia Bożego „do uciekania się z ufną prośbą do s. Faustyny w nagłych potrzebach"70.

Kolejnym ważnym czynnikiem zaznajamiania wiernych z heroicznym życiem s. Faustyny była potrzeba udostępnienia, jeśli nie całości Dzienniczka s. Faustyny, to choćby ich istotnych fragmentów. Rękopis Dzien-

65 Tamże, [Siostra Faustyna Kowalska. Konferencja do kobiet z Akcji Katolickiej, Rzym dn. 2 czerwca 1956], b. sygn.

66 Tamże.

67 Tamże.

68 Tamże, [oświadczenie Zofii Piecyk z dn. 19 IV 1956 r.], b. sygn.

${ }^{69}$ ARMBP, Miłosierdzie Boże..., [list ks. Jana Suchosa do ks. Stanisława Suwały SAC z dn. 1 V 1956 r.], b. sygn.

70 Tamże, [list ks. Stanisława Suwały SAC do ks. Jana Suchosa z dn. 4 III 1956 r.], b. sygn. 
niczka s. Faustyny, który po jej śmierci był w Zgromadzeniu Matki Bożej Miłosierdzia najbardziej strzeżonym dokumentem został na polecenie generalnej Zgromadzenia s. Michaeli Moraczewskiej maszynowo przepisany przez s. Ksawerę Olszamowską i to w sposób daleko odbiegający od oryginału. Jak się okazało niektóre fragmenty oryginalnego tekstu przez ludzką nieuwagę zostały pominięte, pewne określenia zmienione, niektóre wyrazy opuszczone, a niektóre przez s. Ksawerę Olszamowską dodane, co $\mathrm{w}$ zasadzie wypaczało tekst oryginalny ${ }^{71}$. Przez długie lata odpis Dzienniczka s. Faustyny dokonany przez s. Ksawerę Olszamowską uważany był za autentyczny i zgodny z oryginałem. Dopiero w późniejszym okresie ośrodek ołtarzewski księży pallotynów dokonał maszynowego odpisu Dzienniczka w oryginalnym brzmieniu ${ }^{72}$.

S. Ksawera Olszamowska, kierując się wyznaczonymi priorytetami ks. Stanisława Suwały SAC, zapoznała niektóre znaczące osoby Dzienniczkiem s. Faustyny. Tak było w przypadku znanego polskiego literata Władysława Grabskiego, który po lekturze Dzienniczka ocenił go jako „cudny poemat mistyczny" "73. Wskazując potrzebę wydrukowania go w całości bez jakiegokolwiek retuszu, co wówczas byłoby umniejszeniem jego wartości, wykazał wolę napisania ,przedmowy naświetlającej"74. W odpowiedzi ks. Stanisław Suwała SAC wyraził zgodę nie tylko na wydanie Dzienniczka, tym bardziej że o to zabiegał od dłuższego czasu, ale przede wszystkim na przedmowę Władysława Grabskiego, uważając go za osobę kompetentną, który mógłby dobrze naświetlić kwestie zawarte w Dzienniczku i usunąć trudności i podejrzenia w jego rozumieniu ${ }^{75}$.

Cel ten nie został jednak ostatecznie zrealizowany, gdyż pierwsze krytyczne wydanie Dzienniczka datowane na 1983 r. zawierało Przed-

\footnotetext{
${ }^{71}$ J. M r ó w c z y ń s k i, Wprowadzenie, [w:] Dzienniczek Stugi Bożej S. M. Faustyny Kowalskiej..., s. XXVI.

72 M. K o w a lc z y k, Wokół encykliki bł. Jana Pawła II „Dives in Misericordia”. Biuletyn Apostolstwa Miłosierdzia Bożego, R. 2011, nr 46, s. 54.

73 ARMBP, Miłosierdzie Boże..., [list s. Ksawery Olszamowskiej do ks. Stanisława Suwały SAC z dn. 16 II 1957 r.], b. sygn.

74 ARMBP, Miłosierdzie Boże..., [list s. Ksawery Olszamowskiej do ks. Stanisława Suwały SAC z dn. 16 II 1957 r.], b. sygn.

75 Tamże, [list ks. Stanisława Suwały SAC do s. Ksawery Olszamowskiej z dn. 3 III 1957 r.], b. sygn.
} 
mowe ks. abp Andrzeja Deskura oraz Wprowadzenie autorstwa o. Jerzego Mrówczyńskiego ${ }^{76}$.

\section{Problemy postulacyjne i zabiegi o wszczęcie procesu informacyjnego}

Procedura przyjęcia przez pallotynów postulacji budziła zastrzeżenia nawet wśród mianowanych wicepostulatorów. Największe wątpliwości w tej kwestii wyrażał ks. dr Jan Maćkowski SAC, który w liście do ks. Stanisława Suwały SAC wykazywał braki proceduralne, jakie były wymagane przy wszczęciu procesu beatyfikacji s. Faustyny ${ }^{77}$. Kwestionując pallotyńską postulaturę, a przede wszystkim podważając mandat ks. Stanisława Suwały SAC jako postulatora, stwierdził, że właściwemu trybunałowi nie okaże swojej nominacji, by tym samym nie kompromitować Stowarzyszenia Apostolstwa Katolickiego ze względu na niedociągnięcia jurydyczne w tej kwestii. Ponadto sugerował, że w przypadku wyznaczenia przez Świętą Kongregację Obrzędów rzymskiego postulatora należy przed nim ,pochylić czoła, uznać (go) i przyjąć jego mandatum z pokorą"78. Wskazywał równocześnie na potrzebę proceduralną wszczęcia procesu beatyfikacyjnego na szczeblu diecezjalnym i otrzymania mandatu postulatorskiego z rąk ordynariusza miejsca, a nie Matki Generalnej Zgromadzenia Sióstr Matki Bożej Miłosierdzia ${ }^{79}$. Ks. Jan Maćkowski SAC zarzucił wręcz ks. Stanisławowi Suwale SAC, że w myśl przepisów jurydycznych „nie jest postulatorem i nie może mianować swego zastępcy” dopóki wszelkie formalności kanoniczne nie zostaną uruchomione ${ }^{80}$.

Podobne wątpliwości miał ks. Alojzy Misiak SAC skoro na bazie szczątkowo zachowanej korespondencji, omawiającej jego nominację na wicepostulatora, ks. Stanisław Suwała SAC zapewniał go w swoim liście, że jest: „oficjalnie wicepostulatorem sprawy beatyfikacji s. Faustyny na

\footnotetext{
76 Zob. A. M. D e s k u r, Przedmowa, [w:] Dzienniczek Stugi Bożej S. M. Faustyny Kowalskiej..., s. XV-XVIII; J. M r ó w c z y ń s k i, Wprowadzenie, [w:] tamże, s. XXI-XXXI.

${ }_{77}$ ARMBP, Miłosierdzie Boże..., [list ks. Jana Maćkowskiego SAC do ks. Stanisława Suwały SAC z dn. 1 II 1952 r.], b. sygn.

78 Tamże.

${ }^{79}$ ARMBP, Miłosierdzie Boże..., [list ks. Jana Maćkowskiego SAC do ks. Stanisława Suwały SAC z dn. 1 II 1952 r.], b. sygn.

${ }^{80}$ Tamże.
} 
Francję i całą zachodnią Europę" ${ }^{\text {"81 }}$. Również ks. Alojzy Żuchowski SAC, który po rezygnacji ks. Jana Maćkowskiego SAC z powodu choroby, przejął jego obowiązki postulacyjne na Polskę, wypowiadał się w podobnym tonie. Swoją pracę na rzecz beatyfikacji s. Faustyny rozpoczął „od studium kodeksu pro postulatoribus” oraz świątobliwego życia s. Faustyny ${ }^{82}$. W swoim liście wskazywał na formalne uchybienia związane $\mathrm{z}$ datacją mandatu postulatorskiego i delegacji na wicepostulatora. Wykazywał przy tym, że ordynariusz może podważyć jego nominację. Ponadto podnosił te same wątpliwości co ks. Jan Maćkowski SAC w odniesieniu do postulatury pallotyńskiej w kontekście obowiązujących norm kanonicznych. Sugerując, że w międzyczasie mogły wyjść nowe zarządzenia $\mathrm{w}$ odniesieniu procedur kanonizacyjnych, które nie były mu znane, prosił o ich przedstawienie. Żywił przy tym wielkie zaufanie do ks. Stanisława Suwały SAC, podkreślając, że sprawę postulatury pallotyńskiej, mimo zgłaszanych wątpliwości ,dobrze zbadał i przemyślał"83.

W świetle powstałych wątpliwości ks. Stanisław Suwała SAC informował ks. Jana Maćkowskiego SAC, że w sprawie procedury beatyfikacyjnej radził się o. P. Agostino OSST, który prowadził procesy beatyfikacyjne francuskich zakonnic. To on wskazał mu drogę prowadzenia procedury beatyfikacyjnej mimo braku poparcia ordynariusza krakowskiego, ks. abp. Antoniego Baziaka. Mając świadomość całkowitej zależności sprawy beatyfikacji od ordynariusza był pewien, że w momencie otwarcia przez niego procesu na szczeblu diecezjalnym kwestia mandatu może być łatwo uzupełniona ${ }^{84}$. Równocześnie sugerował ks. Janowi Maćkowskiemu SAC, że najważniejszą kwestią jest dobre opracowanie tzw. articuli. Prosząc o ich opracowanie wskazywał, że są one podstawą procesu beatyfikacyjnego ${ }^{85}$.

W 1957 r. spotkał się w Rzymie z ks. prof. Zdzisławem Obertyńskim, który był wicepostulatorem w procesie beatyfikacyjnym s. Mar-

${ }^{81}$ Tamże, [list ks. Stanisława Suwały SAC do ks. Alojzego Misiaka SAC z dn. 12 I 1952 r.], b. sygn.

${ }^{82}$ Tamże, [list ks. Alojzego Żuchowskiego SAC do ks. Stanisława Suwały SAC z dn. 21 III 1952 r.], b. sygn.

${ }^{83}$ Tamże.

${ }^{84}$ ARMBP, Miłosierdzie Boże..., [list ks. Stanisława Suwały SAC do ks. Jana Maćkowskiego SAC z dn. 15 I 1952 r.], b. sygn.

${ }^{85}$ Tamże. 
celiny Darowskiej, założycielki niepokalanek ${ }^{86}$. Przedstawiając mu problemy związane z beatyfikacją s. Faustyny uzyskał od ks. Zdzisława Obertyńskiego zapewnienie pomocy w uruchomieniu procedury beatyfikacyjnej, tym bardziej, że łączyła go nić przyjaźni z ks. abp. Antonim Baziakiem $^{87}$. Wydaje się, że było to zapewnienie na wyrost, zwłaszcza że znany historyk Kościoła „trzymał się w rezerwie” do s. Faustyny, mając: ,pewne fałszywe fakty z jej życia" 88 .

Natrafiając na liczne trudności w realizacji procedury beatyfikacyjnej s. Faustyny, ks. Stanisław Suwała SAC wykorzystywał każdą sposobną okazję, by wzbudzić zainteresowanie tematem nie tylko duchowieństwo polskie, ale i wybitnych hierarchów watykańskich. Na początku 1957 r. nosił się z zamiarem bezpośredniego zwrócenia się do Papieża z prośbą o rozpoczęcie procesu informacyjnego w Rzymie, lecz myśl tę porzucił, uważając, że: „Kraków powinien coś zrobić dla s. Faustyny, by się jej odwdzięczyć za ocalenie" "89. Natomiast siostrę Ksawerę Olszamowską informował, że 1 VI 1957 r. miał zaplanowaną rozmowę z księdzem Prymasem Stefanem kard. Wyszyńskim, który od $6 \mathrm{~V}$ przebywał w Rzymie. Rozmowa miała dotyczyć rozpoczęcia procesu s. Faustyny i nabożeństwa do Miłosierdzia Bożego ${ }^{90}$. Z korespondencji z Marią Winowską dowiadujemy się, że w czasie rozmowy ks. Stanisław Suwała SAC wręczył Prymasowi Polski petycję z podpisami wiernych z całej Polski, sugerując, że nastał odpowiedni czas na beatyfikację s. Faustyny i uznanie święta Miłosierdzia Bożego. O dojrzałości całej sprawy, zdaniem ks. Suwały SAC, świadczyć miała znajomość życia s. Faustyny wśród wiernych i rozwijający się kult Miłosierdzia Bożego tak w kraju, jak i za granicą. Równocześnie, jak stwierdził w liście, zastraszył: „skandalem i kompromitacją Episkopatu, jeśli zagranica nas

${ }^{86}$ F. S t o p n i a k, Ks. Prof. Dr Zdzisław Obertyński (1894-1978), Studia Theologica Varsoviensia, R. 17: 1979, nr 1, s. 7.

87 ARMBP, Miłosierdzie Boże..., [list ks. Stanisława Suwały SAC do s. Ksawery Olszamowskiej z dn. 20 III 1957 r.], b. sygn.

88 Tamże.

${ }^{89}$ Tamże, [list ks. Stanisława Suwały SAC do s. Ksawery Olszamowskiej z dn. 3 II 1957 r.], b. sygn.

90 ARMBP, Miłosierdzie Boże..., [list ks. Stanisława Suwały SAC do Generalnej Zgromadzenia Sióstr Matki Bożej Miłosierdzia s. Szczęsnej Włostowskiej z dn. 31 V 1957 r.], b. sygn. 
w tym wyprzedzi"91. Efektem rozmowy było zapewnienie prymasa Stefana kard. Wyszyńskiego, że na najbliższym posiedzeniu Episkopatu Polski sprawa zostanie wprowadzona w pierwszej kolejności pod obrady $^{92}$. Ponadto prymas Polski w czasie swego pobytu w Rzymie rozmawiał w Kongregacji Świętego Oficjum w sprawie święta Miłosierdzia Bożego, składając otrzymane petycje wiernych. W trakcie prowadzonych rozmów zapoznał się z opinią Kongregacji, że wprowadzenie zmian w liturgii Niedzieli Przewodniej w związku z postulowanym świętem jest niemożliwe, gdyż jej bogactwo treści zawiera już w sobie nawiązanie do Miłosierdzia Bożego ${ }^{93}$. Wyniósł także przekonanie, że odnośnie samego święta Miłosierdzia Bożego Kongregacja nie miała żadnych zastrzeżeń, a sama problematyka była wnikliwie badana przez dykasterię watykańską, która miała wydać w tej sprawie stosowny dekret ${ }^{94}$.

Zainteresowanie Kongregacji Świętego Oficjum kultem Miłosierdzia Bożego i s. Faustyną było w tym okresie dość znaczne. Ks. Stanisław Suwała SAC został poproszony przez prefekta Kongregacji, kard. Alfredo Ottavianiego, na rozmowę w dniu 5 XI 1957 r. ${ }^{95}$. Podczas rozmowy, którą przeprowadził Monsignore Crovini, został poproszony o dostarczenie Kongregacji Dzienniczka s. Faustyny. Ks. Stanisław Suwała SAC po odbytej rozmowie odniósł wrażenie, że Święte Oficjum: „chwilowo jest zainteresowane pismami s. Faustyny", a czerwona sigla na zaproszeniu z nr 65/52 upewniała go w tym przekonaniu ${ }^{96}$.

Ks. Stanisław Suwała SAC odczuwał zażenowanie brakiem uruchomienia procesu informacyjnego na szczeblu diecezjalnym. Niejednokrotnie prosił s. Ksawerę Olszamowską o podanie mu informacji w tej kwestii, zwłaszcza, że od momentu zajęcia się sprawą beatyfikacji s. Faustyny oczekiwał szczęśliwego finału ${ }^{97}$. Irytowała go „przesadna

\footnotetext{
91 Tamże, [list ks. Stanisława Suwały SAC do Marii Winowskiej z dn. 12 XI 1957 r.], b. sygn.

92 Tamże, [list ks. Stanisława Suwały SAC do Marii Winowskiej z dn. 12 XI 1957 r.], b. sygn.

${ }^{93}$ H. C i e r e s z k o, Ks. Michat Sopoćko promotor kultu..., s. 108.

94 Tamże.

95 ARMBP, Miłosierdzie Boże..., [list ks. Stanisława Suwały SAC do Marii Winowskiej z dn. 12 XI 1957 r.], b. sygn.

96 Tamże.

97 Tamże, [list ks. Stanisława Suwały SAC do s. Ksawery Olszamowskiej z dn. 3 II 1957 r.], b. sygn.
} 
ostrożność” oraz ,niepotrzebna i nieuzasadniona przezorność” biskupów polskich ${ }^{98}$. Zwłaszcza nie mógł zrozumieć postawy arcybiskupa krakowskiego Antoniego Baziaka, który nie miał przekonania do heroicznego życia s. Faustyny, a swój brak zainteresowania procesem informacyjnym thumaczył tymczasowością swojego pobytu w Krakowie, swoją chorobą i wiekiem, a przede wszystkim nieodpowiednim momentem zajmowania się tą sprawą ${ }^{99}$. Mimo swoich zapewnień kierowanych w stronę s. Ksawery Olszamowskiej, że jest sympatykiem sprawy i ma nabożeństwo do Miłosierdzia Bożego ${ }^{100}$ nie wykazywał żadnej inicjatywy, by nadać odpowiedni bieg w sprawie beatyfikacji. Z relacji s. Hieronimy Grobickiej wynika, że wahał się z rozpoczęciem procesu informacyjnego $\mathrm{Z}$ powodu ścisłego połączenia osoby s. Faustyny z kultem Miłosierdzia Bożego, który jeszcze nie uzyskał aprobaty i nie był zatwierdzony przez Stolicę Apostolską ${ }^{101}$. Jako ordynariusz krakowski, pomijając wszelkie procedury, prosił jedynie s. Ksawerę Olszamowską o opinie teologów w sprawie s. Faustyny $^{102}$. Siostra Ksawera Olszamowska, która od 1956 r. nie pełniła już urzędu Sekretarki Generalnej Zgromadzenia Sióstr Matki Bożej Miłosierdzia, w dalszym ciągu zajmując się sprawą s. Faustyny, poprosiła wybitnych polskich dogmatyków o. Romualda Kosteckiego OP i ks. Edmunda Eltera SJ o przygotowanie dla abp Antoniego Baziaka opinii dotyczącej s. Faustyny Kowalskiej ${ }^{103}$. Zwłaszcza jezuicki dogmatyk podkreślał świętość jej życia ${ }^{104}$. Jego opinia nie jest żadnym zaskoczeniem, zwłaszcza że ks. Stanisław Suwała SAC już w 1952 r. przedstawiał go s. Ksawerze Olszamowskiej jako swojego serdecz-

\footnotetext{
98 Tamże, [list ks. Stanisława Suwały SAC do Marii Winowskiej z dn. 12 XI 1957 r.], b. sygn.

99 Tamże, [list ks. Stanisława Suwały SAC do Marii Winowskiej z dn. 12 XI 1957 r.], b. sygn.

100 Tamże, [list s. Ksawery Olszamowskiej do ks. Stanisława Suwały SAC z dn. 30 VIII 1952 r.], b. sygn.

101 AZMBMKr., Materiaty dotyczace przygotowania procesu..., [s. Hieronima G r ob i c k a, Chronologiczne dane..., s. 3], sygn. PC/I/1.

102 ARMBP, Miłosierdzie Boże..., [list s. Ksawery Olszamowskiej do ks. Stanisława Suwały SAC z dn. 2 IV 1957 r.], b. sygn.

103 Tamże.

104 Tamże.
} 
nego przyjaciela i sympatyka nabożeństwa do Miłosierdzia Bożego ${ }^{105}$. Po dostarczeniu abp. Antoniemu Baziakowi opinii dwóch dogmatyków s. Olszamowska otrzymała jego zapewnienie, że będzie się jeszcze radził w sprawie otwarcia procesu w Warszawie ${ }^{106}$.

Siostra Ksawera Olszamowska dostrzegając wymijające gesty życzliwości metropolity krakowskiego nie rezygnowała z czynionych starań o uruchomienie diecezjalnego procesu informacyjnego i weszła w bezpośredni kontakt z o. Joachimem Barem OFM oraz Michałem Machejką OCD, którzy instruowali ją w dalszym procedowaniu sprawy. Zwłaszcza o. Joachim Bar OFM namówił ją do pisania artykułów na temat życia i cnót s. Faustyny, które później zostały przyjęte przez o. Izydora Bortkiewicza OFMConv we właściwym procesie informacyjnym na szczeblu diecezjalnym w latach 1965-1967 ${ }^{107}$.

Ks. Stanisław Suwała SAC, dostrzegając olbrzymie trudności i niechęć środowiska kościelnego Krakowa, ale również w Polsce, zastanawiał się nad słusznością wcześniej wyznaczonych priorytetów. Spotykał się z opiniami, że łączenie kultu Miłosierdzia Bożego i beatyfikacji s. Faustyny niekorzystnie wpływa na rozumienie orędzia Miłosierdzia Bożego, a z drugiej strony na heroiczność życia s. Faustyny. Doszedł do wniosku, że trzeba było wpierw dążyć do uznania i zatwierdzenia nabożeństwa do Miłosierdzia Bożego, a następnie zająć się beatyfikacją. Ostatecznie konkludował w liście skierowanym do generalnej Zgromadzenia Sióstr Matki Bożej Miłosierdzia s. Szczęsnej Włostowskiej, że droga, którą do tej pory realizowano: „z wielu względów (...) jest lepsza"108.

Wątpliwości ks. Stanisława Suwały SAC w odniesieniu do wyznaczonych priorytetów i chęć ich zmiany nie były bezpodstawne, zwłaszcza że s. Ksawera Olszamowska informowała go w liście z dn. 16 XII 1957 r. o pojawiających się w Polsce pogłoskach możliwości ukazania się Dekretu Kongregacji Świętego Oficjum tak w sprawie kultu Miłosier-

105 Tamże, [list ks. Stanisława Suwały SAC do s. Ksawery Olszamowskiej z dn. 7 III 1952 r.], b. sygn.

106 Tamże, [list s. Ksawery Olszamowskiej do ks. Stanisława Suwały SAC z dn. 2 IV 1957 r.], b. sygn.

107 AZMBMKr., Materiaty dotyczace przygotowania procesu..., [s. Hieronima G r o b i c k a, Chronologiczne dane..., s. 3-4], sygn. PC/I/1.

108 ARMBP, Miłosierdzie Boże..., [list ks. Stanisława Suwały SAC do Generalnej Zgromadzenia... z dn. 31 V 1957 r.], b. sygn. 
dzia Bożego, jak i s. Faustyny ${ }^{109}$. W odniesieniu do procesu informacyjnego s. Faustyny nie dostrzegała żadnej możliwości jego wszczęcia przez abp. Antoniego Baziaka, który zasłaniał się niechęcią biskupów polskich $\mathrm{w}$ uruchomieniu odpowiednich procedur ${ }^{110}$.

Również ks. Stanisław Suwała SAC miał świadomość przygotowywanego przez Kongregację watykańską specjalnego oświadczenia w sprawie s. Faustyny. Bezpośrednią informację w tej sprawie otrzymał 17 VI 1958 r. od Monsignore Croviniego, który równocześnie informował go, że odpowiednie dekrety ukażą się jeszcze przed wakacjami, choć nie wykluczał przesunięcia terminu ich ukazania się ${ }^{111}$. Nasilające się zewsząd informacje, m. in. od ks. Vivaldelliego, sprawiły, że na początku grudnia 1958 r. ponownie udał się do Kongregacji Świętego Oficjum, gdzie uzyskał potwierdzenie przygotowanego już dokumentu, który został złożony w Kongregacji Obrzędów i stamtąd miał oczekiwać powiadomienia ${ }^{112}$. W dalszej korespondencji upominał ks. Alojzego Misiaka SAC, że z Kongregacją Świętego Oficjum nie można dyskutować, tylko należy podporządkować się jej orzecznictwu. Fakt, że do tej pory specjalny Dekret w sprawie kultu Miłosierdzia Bożego i s. Faustyny nie został jeszcze opublikowany, zdaniem ks. Stanisława Suwały SAC, miało swoją pozytywną stronę. Uważał, że Kongregacja Świętego Oficjum nie ogłosi przygotowanego Dekretu o ile będzie posłuch dla jego treści, która niektórym Zgromadzeniom została już zakomunikowana ${ }^{113}$. Tym samym uważał, że Stolica Apostolska nie chciała nadawać negatywnego rozgłosu w sprawie kultu Miłosierdzia Bożego i objawień s. Faustyny. Dlatego też instruował ks. Alojzego Misiaka SAC, że nabożeństwo do Miłosierdzia Bożego należy rozwijać w oparciu o Pismo św., Tradycję i pisma Ojców Kościoła, a nie według objawień s. Faustyny ${ }^{114}$. Tym samym wskazywał,

${ }^{109}$ AZMBMKr., Materiaty dotyczace przygotowania procesu..., [s. Hieronima G r o b i c k a, Chronologiczne dane..., s. 5], sygn. PC/I/1.

110 Tamże.

${ }^{111}$ ARMBP, Miłosierdzie Boże..., [Wizyta w św. Oficjum, dnia 17. VI. 1958], b. sygn.

112 Tamże, [list ks. Stanisława Suwały SAC do ks. Alojzego Misiaka SAC z dn. 19 I 1959 r.], b. sygn.

113 ARMBP, Miłosierdzie Boże..., [list ks. Stanisława Suwały SAC do ks. Alojzego Misiaka SAC z dn. 25 II 1959 r.], b. sygn.

114 Tamże. 
że w kwestii nabożeństwa do Miłosierdzia Bożego należy motywować go podstawą teologiczną ${ }^{115}$.

Mimo licznie napływających informacji z różnych ośrodków kościelnych jednak zaskoczeniem dla zainteresowanych stron okazała się Notyfikacja Świętego Oficjum z 6 III 1959 r., która zakazywała szerzenie kultu Miłosierdzia Bożego w formie podanej przez s. Faustynę w Dzienniczku ${ }^{116}$. Dekret ten, zawierający 5 punktów, kwestionował nadprzyrodzone pochodzenie objawień s. Faustyny i możliwość ustanowienia święta Miłosierdzia Bożego.

Po ukazaniu się Notyfikacji, ks. Stanisław Suwała SAC prosił w liście do ks. Alojzego Misiaka SAC o dostosowanie się do rozporządzeń Kongregacji Świętego Oficjum ${ }^{117}$. Równocześnie, informując go o zamiarze podjęcia: ,interwencji u odpowiednich czynników”, prosił o zorganizowanie modlitw w okresie od Wielkiego Piątku do Niedzieli Przewodniej celem uproszenia błogosławieństwa Bożego dla jej skuteczności, jak również o odprawianie mszy św. w tej intencji ${ }^{118}$. Ta zawoalowana w swej treści informacja wydaje się być ostatnim etapem postulatorskich działań pallotynów na rzecz beatyfikacji s. Faustyny Kowalskiej, a Notyfikacja Kongregacji Świętego Oficjum położyła kres wszelkim działaniom w sprawie wszczęcia procesu informacyjnego ${ }^{119}$.

Dopiero w 1964 r. nowy ordynariusz krakowski, ks. abp Karol Wojtyła, mając na uwadze uruchomienie procedury wszczęcia procesu informacyjnego s. Faustyny Kowalskiej na szczeblu diecezjalnym, zwrócił się do ks. Stanisława Suwały SAC z prośbą o udzielenie mu informacji dotyczącej rozwoju kultu Miłosierdzia Bożego. Równocześnie pytał go czy ludzie w dalszym ciągu uciekają się w swoich modlitwach do jej wstawiennictwa ${ }^{120}$. Ponadto żądał od ks. Lucjana Baltera SAC, który był głównym organizatorem sympozjów teologicznych w Ołtarzewie, by ich tematyka dotyczyła wyłącznie teologii kultu Miłosierdzia

\footnotetext{
115 Tamże.

116 Acta Apostolicae Sedis, 51 (1959). Ser. III. vol. I. Nr 5, s. 271.

117 ARMBP, Miłosierdzie Boże..., [list ks. Stanisława Suwały SAC do ks. Alojzego Misiaka SAC z dn. 12 III 1959 r.], b. sygn.

118 Tamże.

119 AZMBMKr., Materiaty dotyczace przygotowania procesu..., [s. Hieronima G r ob i c k a, Chronologiczne dane..., s. 6], sygn. PC/I/1.

120 ARMBP, Miłosierdzie Boże..., [list ks. Stanisława Suwały SAC do ks. Alojzego Misiaka SAC z dn. 29 X 1964 r.], b. sygn.
} 
Bożego i w żadnym przypadku nie była wiązana $\mathrm{z}$ tematyką życia i przeżyć duchowych s. Faustyny. To żądanie wynikało z głębokiego przeświadczenia abp. Karola Wojtyły, że rozdzielenie tych spraw jest niezbędne dla prowadzonego w Krakowie procesu beatyfikacyjnego ${ }^{121}$. Tym samym szanując wielki wkład pallotynów w rozwój kultu Miłosierdzia Bożego w Polsce i świecie, a także w ramach organizowanych przez nich sympozjów teologicznych, jak również olbrzymi wysiłek na rzecz, jak się okazało nieudanego uruchomienia procedury beatyfikacyjnej s. Faustyny, metropolita krakowski pragnął doprowadzić proces informacyjny na szczeblu diecezjalnym do szczęśliwego finału.

\section{Wynik prac ks. Alojzego Żuchowskiego SAC}

Po rezygnacji ks. dr. Jana Maćkowskiego SAC z funkcji wicepostulatora na Polskę z powodu jego pogarszającego się stanu zdrowia, ówczesny prowincjał pallotynów ks. Stanisław Czapla SAC desygnował do prac postulatorskich ks. Alojzego Żuchowskiego SAC. W swoim liście do ks. Stanisława Suwały SAC z dn. 21 III 1952 r. ks. Alojzy Żuchowski SAC wyrażał swoje zadowolenie z powierzonego mu zadania, ale także wysuwał swoje obawy $w$ podołaniu odpowiedzialnego „za sprawę Bożą" obowiązku ${ }^{122}$. Jego lęk ustawał z chwilą uświadomienia sobie, że postępuje drogą posłuszeństwa i powierzenia się Miłosierdziu Bożemu ${ }^{123}$.

Z dostępnych źródeł archiwalnych trudno jest określić jego wysiłek w przygotowanie odpowiednich materiałów na bazie badań osób znających s. Faustynę celem uruchomienia procesu beatyfikacyjnego Apostołki Miłosierdzia Bożego. Trudno jest też stwierdzić jaką pracę w tym zakresie wykonał jego poprzednik na urzędzie ks. dr Jan Maćkowski SAC. Wprawdzie w pracy postulacyjnej pomagały im Siostry ze Zgromadzenia Matki Bożej Miłosierdzia, m.in. s. Bernarda Wilczek, która od rodziny s. Faustyny zebrała poświadczone pisemnie

${ }^{121}$ L. B a 1 t e r, Poświęcenie świata Bożemu Miłosierdziu. [W:] Kolekcja Communio, t. 15: Bóg bogaty w Miłosierdzie, Poznań 2003, s. 7; T e nż e, Wprowadzenie, [w:] Powołanie człowieka, t. 5: Wobec tajemnicy Bożego Miłosierdzia, Poznań 1991, s. 6.

122 ARMBP, Miłosierdzie Boże..., [list ks. Alojzego Żuchowskiego SAC do ks. Stanisława Suwały SAC z dn. 21 III 1952 r.], b. sygn.

123 Tamże. 
opinie o Apostołce Miłosierdzia Bożego ${ }^{124}$. Ponadto wszystkie siostry Zgromadzenia, które znały s. Faustynę, na polecenie generalnej Zgromadzenia Matki Bożej Miłosierdzia, pisemnie złożyły swoje zeznania $^{125}$. W dość krótkim czasie ks. Alojzy Żuchowski SAC na podstawie zebranych materiałów opracował 29. stronicowy dokument tzw. articulo, w którym podał tezy i artykuły mające służyć do wykazania heroiczności życia s. Faustyny w procesie informacyjnym ${ }^{126}$.

Przedstawiony przez ks. Alojzego Żuchowskiego SAC dokument nie ma znamion właściwego opracowania articuli zgodnego z normami kanonicznymi. Wprawdzie zawiera jego podstawowe elementy, ale daleki jest od doskonałości jurydycznej. Nie posiada on wykazu materiałów archiwalnych, na bazie których został opracowany. Ponadto dokument nie przedstawia bibliografii źródeł oraz prac nie drukowanych i drukowanych o s. Faustynie, a tym bardziej nie ujmuje opracowań naukowych czy popularno-naukowych, a na pewno w tym momencie, choć nieliczne, już istniały. Dokument w żadnym wypadku nie wskazuje autentyczności i wiarygodności zachowanych akt, świadectw i innych dokumentów, choćby Dzienniczka, związanych z s. Faustyną. Nie ma też żadnego zapisu, że dokument, zwłaszcza życiorys s. Faustyny, był pisany na bazie oryginalnych dokumentów lub uwierzytelnionych kopi. Tym bardziej brakuje stwierdzenia, że zebrane dokumenty pod względem treści nie zawierają żadnych błędów przeciwko wierze i dobrym obyczajom (contra fides et mores).

Analiza dokumentu opracowanego przez ks. Alojzego Żuchowskiego SAC nasuwa wątpliwości, co do rzetelności wykonanej przez niego pracy, zwłaszcza że po każdym większym fragmencie opisu czy to życiorysu s. Faustyny czy po opisach poszczególnych cnót jak mantra powtarza się zapisana formuła ,jak to potwierdzą świadkowie dobrze poinformowani, którzy podadzą źródła swej wiedzy, a mianowicie, że tak słyszeli, że tak czytali, że tak powszechnie jest wiadomo, że tak twierdzą dokumenty autentyczne"127.

\footnotetext{
${ }^{124}$ AZMBMKr., Materialy dotyczace przygotowania procesu..., [s. Hieronima G r o b i c k a, Chronologiczne dane..., s. 1], sygn. PC/I/1.

125 Tamże.

126 Tamże, Materiały dotyczace przygotowania procesu..., [Ks. Alojzy Ż u c h o w s k i, Krakowska Diecezja. Sprawa Beatyfikacji..., s. 2-5], sygn. PC/I/1.

127 AZMBMKr., Materialy dotyczące przygotowania procesu..., [Ks. Alojzy Ż u c h o w s k i, Krakowska Diecezja. Sprawa Beatyfikacji..., s. 2], sygn. PC/I/1.
} 
Całość dokumentu przedstawionego przez ks. Alojzego Żuchowskiego SAC podzielona jest na 3 części. Pierwsza część przedstawia życiorys s. Faustyny, ukazując jej pochodzenie, życie sakramentalne, a także wpływ środowiska, w którym przyszło jej żyć i pracować, na rozwój jej życia duchowego ${ }^{128}$. Wydaje się, że brak ukazania w dokumencie kontekstu społeczno-religijnego okresu, w którym żyła s. Faustyna, nie pozwolił autorowi dokumentu na wyrazistsze przedstawienie jej sylwetki duchowej.

Część druga dokumentu, najbardziej obszerna (s. 5-23), przedstawia „cnoty heroiczne Służebnicy Bożej”" kie cnoty teologalne (wiara, nadzieja, miłość Boga i bliźniego), kardynalne (roztropność, sprawiedliwość, wstrzemięźliwość, męstwo), cnoty pokrewne (pokora, ubóstwo, czystość), a z walorów eklezjalnych, posłuszeństwo. Oddzielnym działem w omawianej części uwypuklony został dar nadprzyrodzony w tym przepowiadania przyszłości, rozpoznawania duchów i przenikania serc „dotyku Bożego” oraz nadprzyrodzonego wpływu na dusze ${ }^{130}$. Omawiając heroiczną miłość Boga u s. Faustyny (s. 11) ks. Alojzy Żuchowski SAC uwypuklił jej uwielbienie Miłosierdzia Bożego. Wskazał, że jej miłość do Boga objawiała się w zachowywaniu wszystkich przykazań Bożych i kościelnych, a także przez znoszenie cierpień i doświadczeń, w których widziała miłującą rękę Boga ${ }^{131}$. Słabo jednak został wyakcentowany element związany z kultem Eucharystii w jej życiu, która jest nie tylko aktem kultu chrześcijańskiego, ale i wyrazem uobecnienia w życiu chrześcijańskim misterium Jezusa, biorącym swój początek z Ostatniej Wieczerzy. Wyakcentowanie tego kultu mogło pomóc ks. Alojzemu Żuchowskiemu SAC do ujęcia heroiczności cnót w świetle objawień Jezusa Miłosiernego s. Faustynie w dniu 20 XII 1934 r. (objawienie 16.) ${ }^{132}$ i z końca stycznia 1935 r. (objawienie 18. ${ }^{133}$. Całkowicie pominięty został w dokumencie kult Matki Najświętszej, zwłaszcza że w liście do ks. Józefa Andrasza SJ z dn. 24 V 1933 r. s. Faustyna opisała 7. objawienie, które nie jest ujęte

\footnotetext{
128 Tamże, s. 2-5.

129 Tamże, s. 5-23.

130 AZMBMKr., Materiały dotyczace przygotowania procesu..., [Ks. Alojzy Ż u c h o w s k i, Krakowska Diecezja. Sprawa Beatyfikacji..., s. 21-23], sygn. PC/I/1.

131 Tamże, s. 11.

$132 \mathrm{Dz} .344$.

${ }^{133} \mathrm{Dz} .370$.
} 
w Dzienniczku. W swoim orędziu Matka Boża nakazała s. Faustynie, by „odważnie mówiła o Miłosierdziu Boga względem ludzi”134. Być może ks. Alojzemu Żuchowskiemu SAC nie był znany ten fakt, a być może nie ujmował $w$ swoim dokumencie niesprawdzonych informacji, choć istnieje podejrzenie, że sam ks. Józef Andrasz SJ mógł tego listu s. Faustyny nie przedstawić podczas zeznania. Nie mniej jednak fakt pominięcia kultu Matki Najświętszej w życiu s. Faustyny jest wyraźnym zaniedbaniem autora articuli.

Trzecią część dokumentu stanowi opinia świętości życia s. Faustyny tzw. fama sanctitatis. Zawiera ona opis „błogosławionej śmierci”, opinie świętości i łaski przypisywane jej wstawiennictwu ${ }^{135}$. W tej części dokumentu ks. Alojzy Żuchowski SAC przedstawia ostatnie chwile życia s. Faustyny, jej pobyt w szpitalu na Prądniku, pogodne znoszenie cierpienia oraz śmierć w klasztorze w Łagiewnikach. Przedstawiając opinię świętości za jej życia i po śmierci wskazywał na szczególne cechy s. Faustyny, jak wyróżniającą się pobożność czy też wzór cnót ${ }^{136}$. Na szczególną uwagę zasługuje w tej części dokumentu opis uzyskiwanych łask za wstawiennictwem s. Faustyny. Wśród pierwszych osób wymienionych w dokumencie, które doznały łaski uzdrowienia za wstawiennictwem s. Faustyny, wymienia ks. Alojzy $\dot{Z} u-$ chowski SAC Barbarę Klossównę z Warszawy, Stefana Zdrojewskiego ze wsi Biała w powiecie płockim, s. Sebastianę Wąsik ze Zgromadzenia Służebnic Najświętszego Serca Pana Jezusa, Genowefę Sandarowicz z powiatu opoczyńskiego oraz Annę Kieloch ze Śląska. Uzdrowienia dotyczyły takich chorób jak gruźlica kręgów szyjnych, choroby płuc z diagnozą wyjściową choroby wątroby, żółtaczki, niewydolności nerek i serca, lewostronnego zapalenia opłucnej z komplikacjami przerostu lewej komory serca i niewydolności naczyń wieńcowych, zapalenia opon mózgowych oraz zakrzepu żylnego ${ }^{137}$.

Na podstawie złożonego na początku dokumentu i przypomnianego na jego końcu oświadczenia można wnioskować, że ks. Alojzy Żu-

\footnotetext{
${ }^{134}$ I. R ó ż y c k i, Nabożeństwo do Miłosierdzia Bożego, Kraków 2010, s. 13, przypis $\mathrm{nr} 3$.

${ }^{135}$ AZMBMKr., Materiaty dotyczace przygotowania procesu..., [Ks. Alojzy Ż u c h o w s k i, Krakowska Diecezja. Sprawa Beatyfikacji..., s. 23-28], sygn. PC/I/1.

${ }^{136}$ AZMBMKr., Materiaty dotyczace przygotowania procesu..., [Ks. Alojzy Ż u c h o w s k i, Krakowska Diecezja. Sprawa Beatyfikacji..., s. 24], sygn. PC/I/1.

137 Tamże.
} 
chowski SAC zastrzegał sobie możliwość uzupełnienia go w razie potrzeby, ale wykluczał obarczania się: „ciężarem dowodzeń zbytecznych”. Dokonany zapis daje podstawy sądzenia, że dokument ten był jedynie przyczynkiem do właściwego opracowania tez i artykułów, które miały posłużyć do właściwego procesu beatyfikacyjnego. Zastanawiać się można jedynie czy w przeciągu niespełna pół roku od powołania go na urząd wicepostulatora (7 III 1952) ${ }^{138}$ mógł rzetelnie wykonać swoją pracę. Wprawdzie przez pewien czas zamieszkiwał w klasztorze Sióstr Zgromadzenia Matki Bożej Miłosierdzia w Józefowie (Lagiewnikach) celem rozpoznania i pracy na rzecz beatyfikacji s. Faustyny, ale już w sierpniu 1952 r. chciał opuścić klasztor w Józefowie nad czym ubolewała s. Ksawera Olszamowska w liście skierowanym do prowincjała pallotynów, ks. Stanisława Czapli SAC, z dn. 17 VIII 1952 r. $^{139}$. W liście tym usilnie prosiła prowincjała, by pozostawił ks. Alojzego Żuchowskiego SAC przy Zgromadzeniu zwłaszcza, że zgodnie z zaleceniem kapituły całe Zgromadzenie Sióstr Matki Bożej Miłosierdzia miało zostać poświęcone Miłosierdziu Bożemu w dn. 1 XI 1952 r. Ich pragnieniem było przygotowanie do tego aktu przez ks. Alojzego Żuchowskiego SAC ${ }^{140}$. Ostatecznie wg relacji s. Hieronimy Grobickiej, ks. Alojzy Żuchowski SAC jeszcze przez pewien czas pozostawał na Kopcu w Wadowicach, by latem 1953 r. podjąć pracę duszpasterską w Warszawie. Wraz z podjęciem nowych obowiązków ostatecznie zrzekł się urzędu wicepostulatora ${ }^{141}$.

\section{Podsumowanie}

Niezaprzeczalną wartością doktryny chrześcijańskiej stało się orędzie Bożego Miłosierdzia przekazane przez Chrystusa jego powiernicy s. Faustynie Kowalskiej (1905-1938). Dynamika 82 objawień, które zostały zapisane w Dzienniczku i dotyczyły nabożeństwa Miłosierdzia Bożego i przywiązanych do niego obietnic związanych ze czcią obrazu

\footnotetext{
${ }^{138}$ ARMBP, Miłosierdzie Boże..., [list ks. Alojzego Żuchowskiego SAC do ks. Stanisława Suwały SAC z dn. 21 III 1952 r.], b. sygn.

139 AZMBMKr., Materiaty dotyczace przygotowania procesu..., [s. Hieronima G r o b i c k a, Chronologiczne dane..., s. 2], sygn. PC/I/1.

${ }^{140}$ AZMBMKr., Materiaty dotyczace przygotowania procesu..., [s. Hieronima G r ob i c k a, Chronologiczne dane..., s. 2], sygn. PC/I/1.

141 Tamże, s. 3.
} 
Jezusa Miłosiernego, ustanowienia święta Miłosierdzia oraz Koronki do Miłosierdzia Bożego, Godziny Miłosierdzia, a także wymaganie ufności w Boże Miłosierdzie i szerzenie jego czci, jak również czynów miłosierdzia ujawniło bogate życie wewnętrzne s. Faustyny i uczyniło ją Apostołką Miłosierdzia Bożego.

Szybko rozchodząca się wieść o życiu skromnej i prostej zakonnicy ze Zgromadzenia Sióstr Matki Bożej Miłosierdzia i przekazane jej przez Pana Jezusa orędzie Miłosierdzia, do którego ludzkość winna się uciekać, przyczyniła się do szybkiego i natychmiastowego rozwoju kultu Miłosierdzia Bożego. Pozyskiwanie zdroju łask za wstawiennictwem s. Faustyny stało się pilną potrzebą uznania święta Miłosierdzia Bożego i uznania Apostołki Miłosierdzia Bożego za świętą. Oddolna inicjatywa $\mathrm{w}$ tych zabiegach przyczyniła się do wielu komplikacji, które ukazały ostrożność, a tym bardziej obawy doktrynalne ówczesnego Episkopatu Polski.

W szerzenie kultu Miłosierdzia Bożego zaangażowały się zgromadzenia księży pallotynów i marianów, a także Siostry Matki Bożej Miłosierdzia, jak również spowiednicy s. Faustyny, bł. ks. Michał Sopoćko i ks. Józef Andrasz SJ. Zwłaszcza pallotyni, celem rozwiania doktrynalnych wątpliwości poprzez organizowane sympozja naukowe, poszukiwali wraz z ośrodkami naukowymi wpierw KUL-u, a następnie także warszawskiej ATK podstaw naukowych do uznania przez Kościół Miłosierdzia Bożego jako przymiotu Boga. Równocześnie Zgromadzenie Sióstr Matki Bożej Miłosierdzia czyniło starania o rozpoczęcie procesu beatyfikacyjnego s. Faustyny Kowalskiej, napotykając w tej kwestii opór niektórych biskupów, w tym metropolity krakowskiego abp. Antoniego Baziaka. Nie widząc szans na uskutecznienie procesu informacyjnego na szczeblu diecezjalnym Zgromadzenie Sióstr Matki Bożej Miłosierdzia zwróciło się do generała pallotynów o pomoc $\mathrm{w}$ procesie beatyfikacyjnym i podjęcie postulatury. Zgoda generała pallotynów, ks. Wojciecha Turowskiego SAC, przyczyniła się do uruchomienia działań zmierzających do uskutecznienia procesu beatyfikacyjnego s. Faustyny. Jak się okazało postulatura pallotyńska nie miała podstaw jurydycznych i nie przyniosła pożądanego skutku, aczkolwiek wniosła wiele w zachowanie pamięci tych, którzy znali osobiście s. Faustynę i za jej wstawiennictwem otrzymywali szczególne łaski.

Autor przedłożenia, pragnąc przywrócić pamięć przeszłości, na bazie dostępnej archiwalnej dokumentacji, zwłaszcza zachowanej korespon- 
dencji, znajdującej się w Archiwum Regi Miłosierdzia Bożego w Paryżu oraz w Archiwum Zgromadzenia Matki Bożej Miłosierdzia w Krakowie i Warszawie, starał się ukazać całość zagadnienia wg porządku metodycznego i chronologicznego ujęcia całości wydarzeń. Żywi tym samym nadzieję, że dalsze kompleksowe badania naukowe oparte na archiwaliach przyczynią się do głębszego naświetlenia omówionego tematu.

\section{Bibliografia}

\section{Źródła archiwalne}

Archiwum Pallotynów w Częstochowie (ASACCz):

Historia kultu Miłosierdzia Bożego. Interpretacja zarządzeń Św. Officjum:

- J. Chróściechowski, Interwencja Najwyższej Kongregacji Świętego Officjum, b. sygn.

Korespondencje 1961-1969.

- List do bpa Stefana Bareły z dn. 21 X 1966 r., b. sygn.

\section{Archiwum Regi Milosierdzia Bożego w Paryżu (ARMBP):}

Miłosierdzie Boże. Siostra Faustyna,

- ks. Alojzy Misiak SAC, Sprawa Akcji „Bożego Miłosierdzia” a Regia Francuska, mps, b. sygn.

- list ks. Alojzego Żuchowskiego SAC do ks. Stanisława Suwały SAC z dn. 21 III 1952 r., b. sygn.

- list generała pallotynów ks. Wojciecha Turowskiego SAC do s. Ksawery Olszamowskiej z dn. 22 V 1951 r., b. sygn.

- list ks. Czesława Wędziocha SAC do ks. Stanisława Suwały SAC z dn. 8 I 1952 r., b. sygn.

- list ks. Henryka Malaka do ks. Stanisława Suwały SAC z dn. 16 V 1955 r., b. sygn.

- list ks. Jana Maćkowskiego SAC do ks. Stanisława Suwały SAC z dn. 1 II 1952 r., b. sygn.

- list ks. Jana Suchosa do ks. Stanisława Suwały SAC z dn. 1 V 1956 r., b. sygn.

- list ks. Juliana Chróściechowskiego MIC do ks. Stanisława Suwały SAC z dn. 26 I 1976 r., b. sygn.

- list ks. Juliana Chróściechowskiego MIC do ks. Stanisława Suwały SAC z dn. 6 VI 1976 r., b. sygn. 
- list ks. Stanisława Suwały SAC do Generalnej Sióstr Zgromadzenia Matki Bożej Miłosierdzia z dn. 25 VII 1951 r., b. sygn.

- list ks. Stanisława Suwały SAC do Generalnej Zgromadzenia Sióstr Matki Bożej Miłosierdzia s. Szczęsnej Włostowskiej z dn. 31 V 1957 r., b. sygn.

- list ks. Stanisława Suwały SAC do ks. Alojzego Misiaka SAC z dn. 12 I 1952 r., b. sygn.

- list ks. Stanisława Suwały SAC do ks. Alojzego Misiaka SAC z dn. 5 IV 1952 r., b. sygn.

- list ks. Stanisława Suwały SAC do ks. Alojzego Misiaka SAC z dn. 19 I 1959 r., b. sygn.

- list ks. Stanisława Suwały SAC do ks. Alojzego Misiaka SAC z dn. 25 II 1959 r., b. sygn.

- list ks. Stanisława Suwały SAC do ks. Alojzego Misiaka SAC z dn. 12 III 1959 r., b. sygn.

- list ks. Stanisława Suwały SAC do ks. Alojzego Misiaka SAC z dn. 29 X 1964 r., b. sygn.

- list ks. Stanisława Suwały SAC do ks. Jana Maćkowskiego SAC z dn. 15 I 1952 r., b. sygn.

- list ks. Stanisława Suwały SAC do ks. Jana Suchosa z dn. 4 III 1956 r., b. sygn.

- list ks. Stanisława Suwały SAC do Marii Winowskiej z dn. 12 XI 1957 r., b. sygn.

- list ks. Stanisława Suwały SAC do s. Ksawery Olszamowskiej z dn. 7 III 1952 r., b. sygn.

- list ks. Stanisława Suwały SAC do s. Ksawery Olszamowskiej z dn. 3 II 1957 r., b. sygn.

- list ks. Stanisława Suwały SAC do s. Ksawery Olszamowskiej z dn. 3 III 1957 r., b. sygn.

- list ks. Stanisława Suwały SAC do s. Ksawery Olszamowskiej z dn. 20 III 1957 r., b. sygn.

- list o. Skudrzyka SJ do ks. Stanisława Suwały SAC z dn. 1 V 1953, b. sygn.

- list s. Ksawery Olszamowskiej do generała pallotynów ks. Wojciecha Turowskiego SAC z dn. 27 II 1951 r., b. sygn.

- list s. Ksawery Olszamowskiej do ks. Stanisława Suwały SAC z dn. 23 VI 1951 r., b. sygn.

- list s. Ksawery Olszamowskiej do ks. Stanisława Suwały SAC z dn. 14 X 1951 r., b. sygn.;

- list s. Ksawery Olszamowskiej do ks. Stanisława Suwały SAC z dn. 1 XI 1951 r., b. sygn.

- list s. Ksawery Olszamowskiej do ks. Stanisława Suwały SAC z dn. 30 VIII 1952 r., b. sygn. 
- list s. Ksawery Olszamowskiej do ks. Stanisława Suwały SAC z dn. 16 II 1957 r., b. sygn.

- list s. Ksawery Olszamowskiej do ks. Stanisława Suwały SAC z dn. 2 IV 1957 r., b. sygn.

- Okólnik Przełożonego Regii do członków Stowarzyszenia Apostolstwa Katolickiego z dn. 5 I 1952 r., b. sygn.

- oświadczenie Zofii Piecyk z dn. 19 IV 1956 r., b. sygn.

- Siostra Faustyna Kowalska. Konferencja do kobiet z Akcji Katolickiej, Rzym dn. 2 czerwca 1956, b. sygn.

- Wizyta w św. Oficjum, dnia 17. VI. 1958, b. sygn.

\section{Archiwum Zgromadzenia Sióstr Matki Bożej Miłosierdzia w Krakowie (AZMBMKr.),}

Materiały dotyczace przygotowania procesu informacyjnego s. Faustyny.

- Ks. Alojzy Żuchowski, Krakowska Diecezja. Sprawa Beatyfikacji i Kanonizacji Stużebnicy Bożej Marii Faustyny Kowalskiej Profeski Koadiutorki Zgromadzenia SS. Matki Bożej Miłosierdzia, sygn. PC/I/1.

- s. Hieronima Grobicka, Chronologiczne dane dotyczace przygotowań, przez M. Ksawerę Olszamowska, procesu informacyjnego s. Faustyny Kowalskiej w latach 1949-1959, sygn. PC/I/1.

\section{Źródła drukowane}

Acta Apostolicae Sedis, 51(1959) Ser. III, vol. I, Nr 5, s. 271.

Dzienniczek Stugi Bożej S. M. Faustyny Kowalskiej Profeski wieczystej Zgromadzenia Matki Bożej Miłosierdzia, Kraków 1983.

\section{Opracowania}

Bakalarz J., Francja. Kościót katolicki, F. Duszpasterstwo polonijne, [w:] Encyklopedia katolicka, t. 5. Lublin 1989, kol. 616-618.

Balter L., Poświęcenie świata Bożemu Miłosierdziu, [w:] Kolekcja Communio, t. 15: Bóg bogaty w Miłosierdzie, Poznań 2003, s. 5-20.

Balter L., Wprowadzenie, [w:] Powołanie człowieka, t. 8: Wobec tajemnicy Bożego Miłosierdzia, Poznań 1991, s. 5-10.

Balter L., Wstęp, [w:] Powołanie człowieka, t. 2: ,...Bo Jego Miłosierdzie na wieki”, Poznań-Warszawa 1972, s. 5-15.

Bednarek A., Jarzębowski Józef MIC, [w:] Encyklopedia katolicka, t. 7, Lublin 1997, kol. 1057-1058.

Błaszczyk T., Wkład Pallotynów w rozwój kultu Miłosierdzia Bożego, [w:] Kościół w Polsce, Dzieje i kultura, red. J. Walkusz, Lublin 2018, s. 265-300.

Cegiełka F., Siostra Faustyna Kowalska - Szafarka Mitosierdzia Bożego, Nord Tonawanda 1954. 
Cegiełka F., Z historii kultu Miłosierdzia Bożego w świecie, Collectanea Theologica, R. 1982, nr 1, s. 145-156.

Chróściechowski J., Historia nabożeństwa do Miłosierdzia Bożego w naszych czasach, Lower Bullingham, Hereford 1977, wyd. 3 poszerzone.

Ciereszko H., Ks. Michat Sopoćko promotor kultu Miłosierdzia Bożego. Saeculum Christianum, R. 11: 2004, nr 2, s. 101-132.

Deskur A. M., Przedmowa, [w:] Dzienniczek Stugi Bożej S. M. Faustyny Kowalskiej Profeski wieczystej Zgromadzenia Matki Bożej Miłosierdzia. Kraków 1983, s. XV-XVIII.

Ewangelia mitosierdzia, red. W. G r a n a t, Poznań-Warszawa 1970.

Forycki R., Kult Miłosierdzia Bożego w świetle encykliki „Haurietis Aquas”,

[w:] Powołanie człowieka, t. 2, „....Bo Jego Miłosierdzie na wieki” (Ps. 135). Poznań-Warszawa 1972, s. 97-103.

Gomułczak F., Cegietka. Pasterz Polonii. Ząbki 2014.

Kisiel E., Bóg - Ojcem miłosierdzia, Biuletyn Miłosierdzia Bożego, R. 1984, nr 14, s. 52-65.

Kowalczyk M., Wokót encykliki bt. Jana Pawła II „Dives in Misericordia”. Biuletyn Apostolstwa Miłosierdzia Bożego, R. 2011, nr 46, s. 50-63.

Ku czci Bożego Miłosierdzia. [w:] Dzienniczek Stugi Bożej S. M. Faustyny Kowalskiej Profeski wieczystej Zgromadzenia Matki Bożej Miłosierdzia. Kraków 1983, s. 728.

Machniak J., Maria Angela Truszkowska, [w:] Encyklopedia katolicka, t. 11, Lublin 2006, kol. 1298.

Misiak A., O Miłosierdziu Bożym. Wyjątki z „Dzienniczka” siostry Faustyny (ze Zgromadzenia Matki Boskiej Miłosierdzia), Paryż 1953.

Misiak A., Siostra Maria Faustyna a Matka Najświętsza, Nasza Rodzina, R. 1955 , nr 5, s. 78-79.

Mrówczyński J., Wprowadzenie, [w:] Dzienniczek Stugi Bożej S. M. Faustyny Kowalskiej Profeski wieczystej Zgromadzenia Matki Bożej Miłosierdzia. Kraków 1983, s. XXI-XXXI.

Nowak S., Ustanowienie święta Miłosierdzia i jego konsekwencje pastoralne. [Referat wygłoszony podczas IV Międzynarodowego Kongresu Apostołów Bożego Miłosierdzia w Krakowie-Łagiewnikach, 3-5 października 2014], mps.

Pietrzyk A. M., Pallotyni zawsze wierzyli w prawdziwość przestania siostry

Faustyny, Annuntianda, R. 24: 2016, nr 265, s. 63-75.

Różycki I., Nabożeństwo do Miłosierdzia Bożego, Kraków 2010.

Różycki I., Zasadnicze rysy nabożeństwa do Miłosierdzia Bożego, Wiadomości Diecezjalne, Organ Urzędowy Kurii Diecezjalnej w Katowicach, R. 57: 1989, nr 3, s. 108-127.

Ryś G., Różycki Ignacy, [w:] Słownik Polskich Teologów Katolickich, red. J. Mandziuk, t. 8, Warszawa 1995, s. 494-496. 
Siepak E., Kowalska Faustyna, [w:] Encyklopedia katolicka, t. 9. Lublin 2002, kol. 1085.

Socha P., Rozwój kultu Bożego Miłosierdzia w Polsce i na świecie, Peregrinus Cracoviensis, R. 2000, z. 9, s. 111-144.

Sopoćko M., Dziennik. Białystok 2015.

Stopniak F., Ks. Prof. Dr Zdzisław Obertyński (1894-1978), Studia Theologica Varsoviensia, R. 17: 1979, nr 1, s. 5-14.

Tylus S., Kalendarium dziejów Regi Miłosierdzia Bożego (1946-2016). Warszawa 2017, mps.

Tylus S., Leksykon polskich pallotynów (1915-2012), Ząbki-Poznań 2013.

Tylus S., Prace polskich pallotynów wśród emigracji (do utworzenia francuskiej regii Miłosierdzia Bożego - 2 VIII 1946), Archiwa, Biblioteki i Muzea Kościelne, t. 66: 1996, s. 464-521.

Winowska M., Droit á la Miséricorde, Paryż 1958.

Winowska M., L'lcône du Christ Miséricordieux. Message de Soeur Faustine, Paryż 1973.

Winowska M., Prawo do Miłosierdzia. Postannictwo siostry Faustyny. Paryż 1974.

KS. TOMASZ BŁASZCZYK

\section{TAK ZWANA POSTULATURA PALLOTYŃSKA PROCESU BEATYFIKACYJNEGO S. FAUSTYNY KOWALSKIEJ}

Streszczenie: Objawienia s. Faustyny Kowalskiej przyczyniły się do rozpowszechnienia kult Miłosierdzia Bożego dzięki jego promotorom bł. ks. Michała Sopoćki oraz zgromadzeniom zakonnym pallotynów i marianów oraz sióstr Matki Bożej Miłosierdzia. Mimo wydanej przez Święte Oficjum Notyfikacji, zakazującej szerzenie kultu w formie podanej przez s. Faustynę w Dzienniczku, promotorzy kultu nie ustawali w wysiłkach przybliżania istoty przymiotu Boga, ale i samej s. Faustyny czyniąc zabiegi o jej beatyfikację. Pallotyni na prośbę s. Ksawery Olszamowskiej ZMBM podjęli się procedury procesu beatyfikacyjnego, co w ostateczności okazało się zabiegiem pozbawionym mocy prawnej. Ich wysiłki zostały uwieńczone 29.stronicowym dokumentem tzw. articulo, który mógł stać się przyczynkiem i bazą źródłową we właściwym już procesie informacyjnym i beatyfikacyjnym zainicjowanym przez kard. Karola Wojtyłę.

Słowa kluczowe: Św. Faustyna Kowalska, bł. ks. Michał Sopoćko, ks. Jan Maćkowski, ks. Alojzy Misiak SAC, ks. Stanisław Suwała SAC, ks. Wojciech Turowski SAC, ks. Alojzy Żuchowski SAC, s. Ksawera Olszamowska ZMBM. 


\title{
THE SO CALLED PALLOTTINE POSTULATURE OF THE BEATIFICATION PROCESS OF SR. FAUSTYNA KOWALSKA
}

\begin{abstract}
Revelations of Sr. Faustyna Kowalska contributed to the spread of cult of Divine Mercy thanks to Bl. Fr. Michał Sopoćko and the Congregations of Pallottines and Marian Fathers as well as to the Sisters of Our Lady of Mercy. Despite the Notification issued by the Holy Office which forbade to spread the cult in the form proposed by Sr. Faustyna in her Diary [Dzienniczek], the propagators of the cult did not cease in their efforts to promote the essence of God's attributes as well as Sister Faustyna herself by striving for her beatification. At the request of Sr. Ksawera Olszamowska CSBMM, the Pallotines undertook the beatification process, which ultimately turned out to be an act without legal force. Their efforts were crowned with a 29-page document, the so called articulo, which became a contribution and a source base in the actual information and beatification process initiated by Cardinal Karol Wojtyła.
\end{abstract}

Keywords: St. Faustyna Kowalska, Bl. Fr. Michał Sopoćko, Fr. Jan Maćkowski, Fr. Alojzy Misiak SAC, FR. Stanisław Suwała SAC, Fr. Wojciech Turowski SAC, Fr. Alojzy Żuchowski SAC, Sr. Ksawera Olszamowska CSBMM.

Translated by Hanna Rybkowska 
